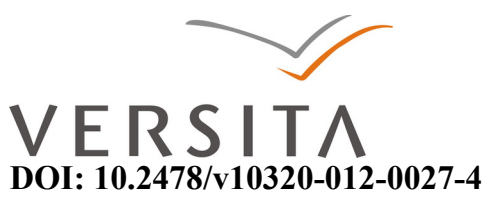

\title{
PATTERNS AND REPRESENTATIONS OF SHAKESPEAREAN LOVE: HUBRIS, INFATUATION, AGAPE IN HAMLET
}

\author{
BIANCA FOGHEL
}

West University, Timişoara,

4, Pârvan Blvd, Timișoara, Romania

foghelbianca@gmail.com

\begin{abstract}
The more conceptually elusive love has proven to be, the more it has whetted humanity's appetite to try to narrow it down. Could one say that Shakespeare is one of the few personalities that managed not only to exemplify almost all recurrent patterns of love, but also to recreate them, in his case, within his plays? Is love weak, or is it so strong that it gives life to a character, only to overwhelm and destroy him/her later? Are there any archetypal emotional stages, or is it a fiery combustion? These are all questions which this paper will attempt to discuss with regard to Hamlet.
\end{abstract}

Keywords: Agape, gender stereotypes, Hubris, love dynamics, women between virtue and evil

Shakespeare's genius has proven to be a source of endless discussions, critical publications and stage representations that have clearly placed him at the head of any list of playwrights, not only in England, but in the whole world. The celebrated figure Shakespeare has become has much to do with the celebrated individuals in his plays.

The present work deals with what is generally accepted as one of Shakespeare's most famous plays, without paying special attention to chronology or other structurerelated issues, but focusing much more on matters of emotional interest in Shakespearean drama, the coexistence of the two genders, its evolution or involution, whether it is constructive or destructive. Alongside these major divisions, I have begun the paper with a brief introduction to the concept of love, as this is the starting point and the favourable environment for the development of inter-gender relationships. 
As mentioned earlier, this analysis focuses on the problematic issue of love, which has at times a very abstract meaning, a meaning that medieval or Renaissance philosophers tried to reshape into a more palpable concept, even though they could never attain the incontestable complexity and depth of Shakespeare, one of the most celebrated figures of the Elizabethan age. It is clear that the patterns revolving around love are construed according to other, broader paradigms, such as that of the social and historical context that to a great extent shape gender dynamics. The deviations that may occur at any paradigmatic level are due to more subtle social co-ordinates such as epistemology, ethics and metaphysics. However, Hamlet's solitary self is set against social custom, which makes him a very early instance of Modernism. Modern interpretations of the play propose strong psychological motivation for him and Freud has taught us much about such contradictory states of mind (since Hamlet both asserts and denies his love for Ophelia), but in part he is responding to Renaissance stereotypes of women. Eve or the Virgin Mary: women were seen either as extremely flawed or as paragons of virtue. Since few real women approach perfection, they are seen as evil, especially vulnerable to the Devil and his wiles, situated between the virginal ingénue and the villainous temptress, but always at an extreme. Ophelia must therefore head for the nunnery, or she will inevitably be corrupted and Gertrude has already fallen:

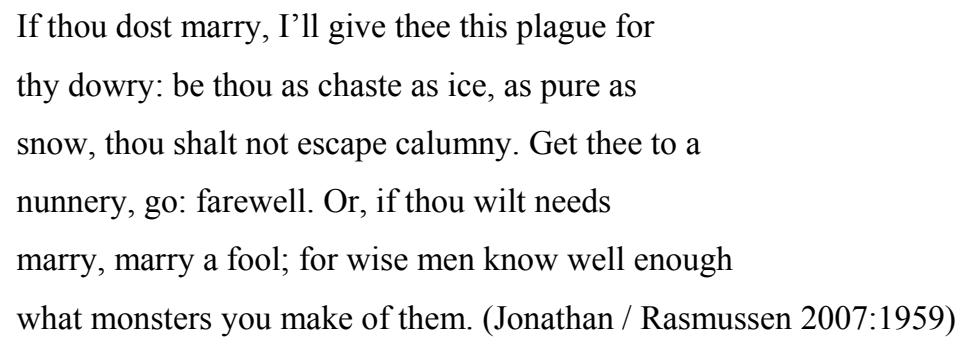

"Women in early modern England, as elsewhere in Europe, benefited from a limited range of scripts as specific contexts in which they lived or as descriptors of their status or character. [...] Female categories were either domestic, with a moral connotation - virgin, wife, mother - or antisocial - scold, whore, witch" (Percec 2006:190). 
During the Middle Ages, the Church was the decisive pillar for most societies; thus, however paradoxically, affective freedom was "dictated" by restrictions and theories that did not always have a positive effect upon people's morale. Sexuality was not seen as an implicit part of a marital relationship, but rather as an act devoid of pleasure and clearly oriented towards leaving heirs and closing a financial deal between the two families involved. By the end of the $11^{\text {th }}$ century, the church was the exclusive owner of marriage.

During the Renaissance, philosophers such as Marsilio Ficino (1433-1499) developed highly elaborate theories relating the idea of love to psychological concepts, much closer in meaning to the contemporary perception of the notion. For that period, Ficino's perspective, which sees love as a game of knowledge as well as an unconscious overlapping of our inner self and the external image of the loved one, brings fineness to the concept, breaking with tradition and setting it on a much higher level in the hierarchy of values. The Renaissance period focuses on the singularity of the individual and so does Ficino. Men and women are equally entitled to express themselves through art, feeling and emotion. The patriarchal society of the Middle Ages was no longer as common in the Renaissance, since this era took both genders into account, feminine beauty and sexuality being as inspiring as masculine. In this context, where order is constantly asserted, the fact that it is a woman who is seen as

\footnotetext{
the cause of the excess and deficiency in the play [...] takes on further resonance, seeming to echo another fundamental drama of psychic experience as described by Freud. This is the drama of sexual difference where the woman appears as the cause of just such a failure in representation, as something deficient, lacking or threatening to the systems and identities which are the precondition not only of integrated artistic form but also of so-called normal adult psychic and sexual life (Rose 1985:96).
}

This is how the idea of the destructive power of love upon the human soul is introduced. Hamlet experiences this collapse, runs it through the filter of his mind, articulates it through his ambiguous language, but is unable to figure out strategies for solving it, because the troubled relationships between men and women are the consequence of a constant interpretation, misinterpretation and reinterpretation of each 
other's feelings and their reliability. The various meanings of words build a linguistic maze, just like the emotional maze built by gender discrepancies, where the Shakespearean heroes lose their way, and hence the opposition between the signified and the signifier, thus the irreversibility of the situation, the final collapse and the hope that the irreversible will become reversible, at least at a spiritual level. It seems that these Shakespearean psychological patterns have continued to reverberate up to the present day, without having lost their applicability to human nature.

The patterns of love in particular are extremely complex and intricate, display enormous powers of representation. Their timelessness is certainly due to their accuracy and psychological reliability: traits and behavioural propensities, even though often deviant, never seem unnatural or without motivation. The reader or the spectator comes to relate to the characters in such a profound way that she/he senses the motivational triggers behind each histrionic act or discourse.

In the case of Hamlet, Ficino has given us the theory of the pathological consequences of love that underlines the essence of the play, the state of mind of the protagonist and the influence of love upon him. Hamlet's constant melancholy is not only the result of the evil eye, his love for Ophelia, but also a consequence of the loss of his ability to love, thus his disgust for femininity and sexuality and his desire for vengeance. Melancholy, hubris and the associated loss of contact with reality take over Hamlet, forcing him to remain on the path of vengeance throughout the play and to experience all its symptoms, namely anomalous behaviour, emotional instability, and an inevitable and gradual loss of sanity. He expects perfection from the other, as he presumably believes himself to be capable of delivering it; Ophelia in particular is burdened with such an expectation of perfection, and Hamlet associates her physical beauty with lecherousness:

\footnotetext{
That if you be honest and fair, your honesty should admit no discourse to your beauty. (Jonathan / Rasmussen 2007:1958)
}

Hamlet experiences his greatest peril when he feels betrayed by Ophelia's love and he himself becomes unable to love and falls into the trap of unfathomable hubris, allowing his idealistic urge for vengeance to take over his entire soul, casting aside any possibility of achieving agape, the only redeeming form of love. Agape, the Greek term 
for pure, spiritual love, is meant to designate the supreme feeling, fiery and serene at the same time, but always authentic. It represents pure Eros, the ascension of the soul towards the supreme union, "beyond all forms of love that are possible in a human's life, therefore a type of love that has nothing to do with marriage" (Percec 2006:235). Ophelia tells of how she witnessed Hamlet uttering a sigh that seemed to "end his being". An end that could also have been considered a beginning: the birth of a new man dedicated to the proposition that the opposite of reason is not madness, but true feeling. However, the clear-mindedness necessary for attaining agape and overcoming his ego eventually eludes him because of his irresolution and inaction. He knows that authenticity of feeling is paramount, but since everything around him seems to reek of betrayal, he cannot devote his extreme self-consciousness to moulding his character powerfully enough. Owing to his highly developed intellectual powers - and his broad and many-sided sympathies, Hamlet can never take a simple view of any question - but always sees a number of different aspects and possible explanations for every problem. A given course of action has never seemed to him unequivocal and obvious, so that in practical life his scepticism and reflective powers have paralysed his conduct. He thus stands for what may roughly be called the type of an intellect over-developed at the expense of the will, held up as a warning example of losing oneself in abstract trains of thought at the expense of contact with reality. He does not even accept that someone else can feel a sorrow as poignant as that he himself experiences; when Laertes bewails the premature death of his sister, Hamlet swiftly intervenes:

What is he whose grief

Bears such an emphasis? whose phrase of sorrow

Conjures the wandering stars, and makes them stand

Like wonder-wounded hearers? This is I,

Hamlet the Dane. (Jonathan / Rasmussen 2007:1990)

And in the same passage he reasserts his love, a love that has undergone too many extreme stages of metamorphosis, from utter abandonment, to denial, rejection and reacceptance: 
I loved Ophelia: forty thousand brothers

Could not, with all their quantity of love,

Make up my sum. What wilt thou do for her? (Jonathan / Rasmussen 2007:1991)

Misogyny, another pattern in gender dynamics, becomes omnipresent in his relationship with women, Ophelia now being constantly rejected, treated with arrogance, insulted and disrespected, while Gertrude is denied as a mother-figure and seen as an incestuous being who is unworthy of his filial affection. Since for the common societal frame sexuality entails danger and “violates property, Gertrude's impropriety ('her 'o'erhasty' marriage') [...] provokes a crisis which overturns the sexual identity of the central male character of the drama. Hamlet, in response to his mother's 'flagrancy', projects the same flagrancy onto the image of the innocent Ophelia" (Rose 1985:97). For Hamlet, Gertrude's blatant sexuality makes her less than human, lacking "discourse of reason" (III. ii. 150), being the victim of infatuation and lust for power.

Therefore, Ophelia is the person that suffers longer-term, since her conflict with Hamlet is not her only problem, her father's death being another reason for her grief. The death of the loved person is the only possible end to the path of vengeance. The prince does not stop until he has destroyed Ophelia, since all he can perceive now in the essence of femininity is the lack of this essence, namely "nothingness". It is as if Hamlet had eradicated a feeling that was potentially going to evolve from sheer infatuation to a pure and requited love. He disrupts with his spite the naturalness of a gradually growing intensity, and everything in his perception converges around the void that remains after Ophelia's love is thrust aside, which he naively hopes to fill again by avenging his father. The love-vengeance association is an archetypal one, and as history and literature have taught us, this is not the first time that the latter has prevailed, stirred by inherent hubris. It seems that the love between Hamlet and Ophelia was a mere combustion that once ablaze burned itself to ashes. Polonius warns Ophelia about the transience of mere infatuation:

When the blood burns, how prodigal the soul

the tongue vows: these blazes, daughter,

Giving more light than heat, extinct in both, 
Even in their promise, as it is a-making,

You must not take for fire. (Jonathan / Rasmussen 2007:1978)

The two women, Gertrude and Ophelia, are equally important for Hamlet's existence, but they differ and are actually opposites in terms of their personalities: one is weak and transparent, while the other is powerful. They both end up dying for the protagonist's sake, for his understanding of the true meaning of things, for the ending of all his questions and dilemmas. However, is Hamlet really in love with Ophelia? And conversely, does Ophelia ever say or do anything to indicate she loves Hamlet or is it all a matter of egocentric infatuation?

Hamlet tells the story from the standpoint of the void itself. The mysterious opacity, the central recalcitrance which baffles and resists interpretation, is none other than woman and desire. In Hamlet that opacity, while closely related to female sexuality, is quite evidently the protagonist himself, whose enigmatic nature is legendary in world literature. The particular form of negativity which Hamlet experiences is melancholia, augmented by hubris which, rather like paranoid jealousy, drains the world of value and dissolves it into nauseating nothingness:

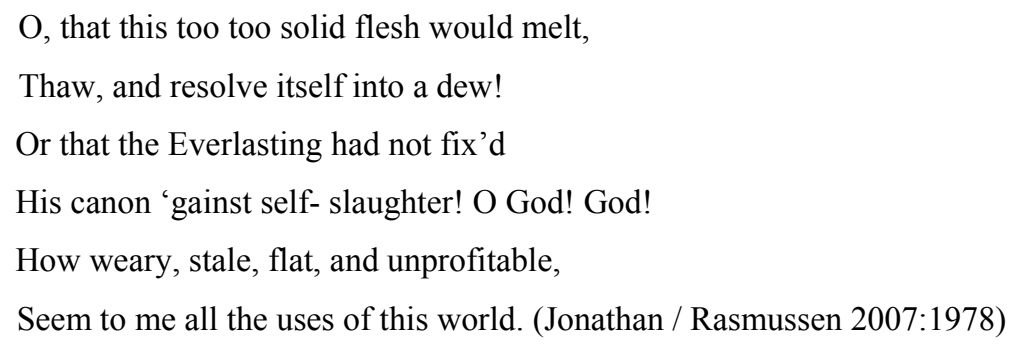

What Hamlet has importantly lost appears to be less his father than his mother, who has committed at least two grievous errors: she has revealed herself capable of desire, a scandalous thing in a woman, let alone in a mother, and that desire is not for Hamlet himself, but for another man. Once the imaginary relation between Hamlet and Gertrude has been ruptured by the entry of Claudius, Hamlet teeters hesitantly on the brink of the symbolic order (the system of allotted sexual and social roles in society), unable and unwilling to take up a determinate position within it. Indeed he spends most of his time eluding whatever social and sexual positions society offers him, whether as 
chivalric lover, obedient avenger or future king. This inner being, as he coldly informs Gertrude, evades the mask of the signifier:

Tis not alone my inky cloak, good mother,

Nor customary suits of solemn black,

Nor windy suspiration of forc'd breath,

No, nor the fruitful river in the eye,

Nor the dejected haviour of the visage,

Together with all forms, moods, shapes of grief,

That can denote me truly. These, indeed, seem;

For they are actions that a man might play;

But I have that within which passes show -

These but the trappings and the suits of woe. (I .ii.77-86)

Hamlet's reluctance or inability to re-enter the symbolic order, and his revulsion from the sexuality which reproduces it, are in one sense regressive states of being. His Oedipal attachment to his mother fragments his being, since it swerves round all determinate objects (Ophelia, filial duty, political power) that cannot be represented other as a lack. But this psychological regression is also, paradoxically, a kind of social progressiveness. Hamlet is a radically transitional figure, stretched out between a traditional social order to which he is marginal, and a future epoch of achieved bourgeois individualism which will succeed it. Because of this we can glimpse in him a negative critique of the forms of subjectivity typical of both these regimes. It is his regressiveness which makes him so modern: eccentric to the traditional order but still oppressed by it, unable to transgress its definitive limits into a fully alternative style of being. This is why many commentators have discerned something peculiarly "modernist" in Hamlet, apart from being one of the earliest representations of the Freudian Oedipal complex and its somewhat extreme manifestations. The French critic Henri Fluchère, who sees Hamlet as "the first Shakespearean drama which can lay claim to both extremes in personality and universality", interprets the play as a symbolic representation of the battle between man and his destiny, his temptations and contradictions. (Johnson, A Lecture on Shakespeare's Hamlet). 
The character of Hamlet could easily be placed in a distant sphere of the incomprehensible and the unknown, since to understand Hamlet is to reflect on the constitution of the human mind. Being a victim of mere meditation, Hamlet has lost his capacity, his natural power of action, thus becoming the drama of a man who does not hesitate to confront his own imperfections and who refuses illusions and idealistic appearances:

What piece of work is a man, how noble in reason, how infinite in faculties, in form and moving how express and admirable, in action how like an angel, in apprehension how like a god: the beauty of the world, the paragon of animals - and yet, to me, what is this quintessence of dust? Man delights not me [...] (Jonathan / Rasmussen 2007:1970)

- Hamlet's response to his friends, Rosencrantz and Guildenstern, when he realises that they are acting on the King's behalf. Hamlet associates the human immanent imperfection of character with that of love, thus rejecting this only redeeming feeling. The tragedy, Fluchère tells us (Johnson, Lecture on Hamlet), takes place above all in Hamlet's consciousness, as all the events which form the play's framework are reduced to a symbolic representation, to an internal unrest which no action will resolve and no decision will quell. The deepest theme, masked by that of vengeance, is none other than human nature itself, confronted by the metaphysical and moral problems moulded by love, time, death, perhaps even the principle of identity and quality, not to say being and nothingness.

The troubles encountered by the young Prince are not only the result of his discovering the murder of his father and the incest committed by his mother and uncle, but also stem from his idealism that causes him to link the whole of humanity to the flaws of those around him. Throughout the play, Hamlet teaches the audience the depths of his depression through soliloquies that convey a very embittered and cynical outlook on life. The foremost cause for his exasperation is repulsion towards his mother's actions, as he cries out - "Frailty, thy name is woman". The Prince develops a burning hatred that goes beyond his mother and extends to women in general. It is this furious mindset that is responsible for his terrible treatment of sweet, innocent Ophelia in Act III. 
However, it is not always like that. Hamlet is theoretically very much in love with Ophelia up to that particular point. The only problem is that we do not see that stage of their relationship, "the very ecstasy of love"; we see neither Hamlet as a lover, nor Ophelia expressing her affection for the Prince of Denmark, because the days when he supposedly expressed his love were before the opening of the drama, before his father's spirit revisited the earth. We only see him as drowning in a sea of trouble, of perplexities, of agonies, of terror. It is as if the reader or the spectator is presented with the ashes of a love prematurely buried in the ground of human flaws.

It has been stated that "in the case of love, the object's image is corrected at the innermost level because of the subject's desire to harmonize it with their most secret aspirations" (Percec 2006:227). What is somewhat sinister is that Hamlet's idealism paradoxically exhibits nihilistic hues, since although powerful enough to create almost palpable associations in his mind it is blinded by hubris and thus lacks the power to redeem Ophelia in his eyes. He admits to Ophelia:

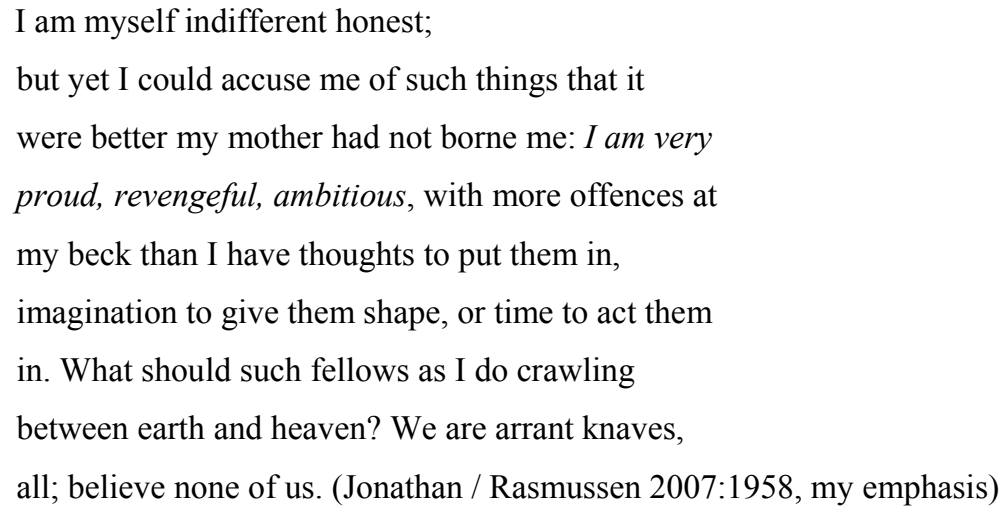

This excessively idealistic ambition might actually be a representation of the Greek term hamartia, a term more properly understood as an error in action rather than as a fatal weakness of character. To think of the tragic hero as afflicted with a 'fatal flaw' is to simplify and misunderstand the complex problem of the tragic protagonist and the society with which he or she is in conflict. "Defining the tragic hero mainly in terms of a flaw makes it too easy for us to pigeonhole the experience of a complicated character and thus insulates us from complicity in that character's responsibility or guilt." (McDonald 1996:169). Hamlet is frequently described as flawed by an inability to make up his mind, 
but the Prince of Denmark is a staunch seeker after truth, a subtle thinker who wants to know the facts and then to act rightly on the basis of what he knows. The play represents the collision between the hero's admirable aim and the traps and obstacles that the world places in his way. Hamlet's hesitation may derive from a "laudable moral repugnance at undertaking the role of the avenging son. [...] But his idealism carries a tragically high price - the death of Polonius, the suffering and suicide of Ophelia, and the entrapment of the hero in the very world he has set out to oppose" (McDonald 1996:170).

During the Middle Ages and subsequently, in the Renaissance period, many questions were asked regarding the human being. On the one hand, the focus of these questions were men and Giovanni Pico della Mirandola considered that when God said man was free to decide for himself about the way in which he wished to live, He was referring to Adam only. Women were considered filthy and were associated with sexuality and sin by the Fathers of the Church, who thought Eve was to be blamed for the original sin. Men who longed for atonement had to stay away from women and women had to stay away from themselves (Verdon 2009:50). Tertullian answers the question "What is a woman?" by listing a long series of vices (the enemy of friendship, a necessary evil, the essence of evil, the primal temptation).

It was very frequent at that time to make a Manichean distinction between the sexes: active-passive, soul-body, good-evil, valuable-useless, and although this distinction was diminished, for Aristotle, woman was considered an error of nature, while for Thomas Aquinas she was "an imperfect man" (Verdon 2009:51). Both Thomas Aquinas and Aristotle thought woman played a very important part in the house, always depending on male authority; the fact that women were indispensable did not mean they were equal.

However, in Shakespeare's dramas women play an important role. Love is a matter that brings about conflicts and interior tensions, but it is definitely needed in order to show the humane side of the characters in general and the protagonist in particular. Hamlet falls in love with the beautiful Ophelia despite the fact that this unleashes a battle between sexes, between Hamlet's highly rational life and Ophelia's instincts, between his philosophical judgment and her romantic vision. 
Ophelia is generally considered the victim of the play. She is a victim of her own weaknesses first of all, a victim of Hamlet, of Gertrude, of her father Polonius and even of King Claudius - Claudius' killing of Hamlet's father brings about Hamlet's scheme to make people think he is mad which brings about the death of Polonius, which leads to Ophelia's death. Her death also raises questions - was it an accident or a suicide?

She is a rather static, one-dimensional character; she is manipulated by most of the people she cares for and although she has the potential to become a tragic heroine, she does not manage to overcome fear and instead crumbles into insanity, becoming merely tragic. Like King Lear, Ophelia finds that in madness she can think and say things that would be impossible in the sanity of a supposedly ordered society. Does she use the language of flowers to attack Gertrude and Claudius? Ophelia's madness, brought on by her frustrated love and the bizarre way her father was killed by her loved one, seems less ambiguous than Hamlet's for her language and behaviour are clearly irrational. Gertrude is, more so than any other character in the play, the antithesis of her son, Hamlet. Hamlet is a scholar and a philosopher, searching for life's most elusive answers. He cares nothing for this "mortal coil" and the vices to which man has become slave.

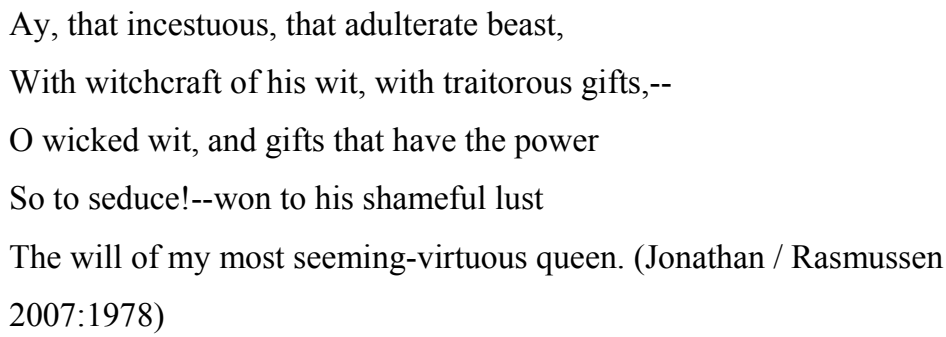

The philosophy of Shakespeare's plays is a careful observation and meditation upon human beings, life and a kaleidoscope of human relations, "by the assimilation of the ancient wisdom; morals is conveyed either in laughter or in the moments of solemn resignation, hesitation or despair. Shakespeare wrote for people's most secret tastes for comedy and tragedy, man's ascent and decline" (Olaru 1976:398). And "the rest is silence".

\section{References}


Bate, J. and E. Rasmussen. 2007. William Shakespeare. Complete Works. Houndmills Basingstoke, Hampshire: Mcmillan.

Johnson, I. 2001. Introductory Lecture on Shakespeare's Hamlet, A Lecture prepared for English 200 and revised for English 366: "Studies in Shakespeare”. [Online]. Available: http://records.viu.ca/ johnstoi/eng366/lectures/hamlet.htm [2011, November 6].

McDonald, R. 1996. The Bedford Companion to Shakespeare. An Introduction with Documents. Boston, New York: Bedford Books of St. Martin's Press.

Olaru, A. 1976. Shakespeare şi Psihiatria Dramatică. Craiova: Editura Scrisul Românesc.

Percec, D. 2006. The Body's Tale. Some Ado about Shakespearean Identities. Timişoara. Editura Universităţii de Vest.

Rose, J. 1985. Sexuality in the Reading of Shakespeare. Hamlet and Measure for Measure, 97-120 in Drakakis, J. Alternative Shakespeares. New York: Routledge.

Verdon, J. 2009. Dragostea în Evul Mediu, Trup și sexualitate. București: Humanitas. 